\title{
Temperature and salinity effects on magnesium, manganese, and barium incorporation in otoliths of larval and early juvenile spot Leiostomus xanthurus
}

\author{
Gretchen Bath Martin ${ }^{1, *}$, Simon R. Thorrold ${ }^{2}$ \\ ${ }^{1}$ NOAA/NOS/NCCOS Center for Coastal Fisheries and Habitat Research, 101 Pivers Island Road, Beaufort, \\ North Carolina 28516, USA \\ ${ }^{2}$ Biology Department, MS \#35, Woods Hole Oceanographic Institution, Woods Hole, Massachusetts 02543, USA
}

\begin{abstract}
The use of otolith chemistry to delineate fish populations and trace migration pathways is premised on a significant correlation between the elemental composition of otoliths and physicochemical properties of the ambient environment. However, few experiments have been rigorously designed to address the effects of temperature and salinity on the elemental composition of otoliths. We examined the effects of temperature and salinity on the incorporation of magnesium (Mg), manganese (Mn), and barium (Ba) in the otoliths of larval and early juvenile spot Leiostomus xanthurus by rearing fish in the laboratory under controlled environmental conditions. L. xanthurus are an estuarine dependent species that traverse varying temperature and salinity regimes throughout their life histories. It is important, therefore, to understand the influence of physicochemical properties of different water masses before attempting to reconstruct important life history transitions based on variations in otolith chemistry. Both $[\mathrm{Mg} / \mathrm{Ca}]_{\text {otolith }}$ and the $\mathrm{Mg}$ partition coefficient, $D_{\mathrm{Mg}}$, were not significantly affected by either temperature or salinity, but were correlated with otolith precipitation and somatic growth rates. Temperature and salinity had significant interaction effects on $D_{\mathrm{Mn}}$, but not on $[\mathrm{Mn} / \mathrm{Ca}]_{\text {otolith. }}$. Finally, $D_{\mathrm{Ba}}$ was influenced by salinity but not temperature. These results highlight the complex nature of elemental deposition in otoliths, and suggest that both environmental and physiological effects likely influence elemental ratios in fish otoliths.
\end{abstract}

KEY WORDS: Otolith chemistry · Temperature · Salinity · Magnesium · Manganese · Barium Resale or republication not permitted without written consent of the publisher

\section{INTRODUCTION}

Elemental signatures in the otoliths of teleost fishes are increasingly being used as natural tags of stock structure and to assess usage of juvenile nursery habitats (Edmonds et al. 1989, Campana et al. 1994, Gillanders \& Kingsford 1996, Begg et al. 1998, Thorrold et al. 2001). Using the elemental composition of fish otoliths to infer population affinities and past environments is based on the assumption that elemental incorporation in otoliths is proportional to the ambient concentration of a particular element in the water. Water bodies have different elemental compositions based on the geochemistry of the watershed, anthropogenic, and natural inputs to the system, and the behavior of elemental species as influenced by complexation, biological uptake, and sorption on suspended solids (Bender et al. 1977, Turner et al. 1981, Bruland 1983, Byrne et al. 1988, Morel \& Hering 1993). In theory, fish with similar elemental signatures in otoliths originated from the same location, while fish with significantly different signatures are assumed to have come from elsewhere. In practice, however, it is not clear that elemental incorporation in otoliths is solely a function of the physicochemical properties of the ambient water mass. Because fisheries management relies on the accurate classification of fish stocks and habitat use, erroneous interpreta- 
tions of geochemical signatures in otoliths could lead, in turn, to illogical management decisions.

Environmental effects on otolith element incorporation may be confounded by the influence of aragonite precipitation rate on element incorporation in biogenic aragonite. Studies on synthetic aragonite have found no effect of precipitation rate on element incorporation (Kinsman \& Holland 1969, Zhong \& Mucci 1989), while studies on biogenic aragonite have been contradictory. Some work has suggested that $\mathrm{Sr} / \mathrm{Ca}$ in corals was correlated with precipitation rates (Weber 1973, deVillers et al. 1994, 1995), although Shen et al. (1996) found no such relationship. In mollusks, Buchardt \& Fritz (1978) found Sr incorporation to be independent of growth rate, but Stecher et al. (1996) speculated that there was a seasonal growth effect on Sr incorporation of 2 species of bivalves. Bath et al. (2000) found no effect of aragonite precipitation rate on $\mathrm{Sr}$ and $\mathrm{Ba}$ incorporation in fish otoliths. However, no information is available for any of the other elements routinely used in otolith chemistry studies.

Physiological processes also influence otolith composition. Otoliths are isolated from seawater by branchial, intestinal, and the endolymphatic membranes, and fish obviously control ion transport across these membranes for osmoregulatory purposes. Elemental concentrations are, therefore, typically lower in otoliths than in the surrounding environment (Campana 1999). Elemental discrimination does not necessarily invalidate the use of otolith chemistry for reconstructing environmental conditions experienced by individual fish, providing that the degree of regulation of a particular element either remains constant (allowing reconstruction of dissolved levels of an element in the environment) or changes predictably with a variable of interest (typically either temperature or salinity). For instance, otolith $\mathrm{Sr}$ has been shown to scale linearly with ambient $\mathrm{Sr} / \mathrm{Ca}$ ratios in the water, with predictable effects of temperature and salinity on Sr partition coefficients (Bath et al. 2000, Kraus \& Secor 2004, Martin et al. 2004). However, similar information is not available for any of the other elements routinely used in analyses of geochemical signatures in otoliths.

Rigorous testing of the factors determining otolith chemistry requires knowledge of the physicochemical properties of the ambient water and the physiological attributes of the fish assigned to different treatments (e.g. Bath et al. 2000). However, few experiments have addressed the influence of temperature and salinity on elemental composition of otoliths with the necessary environmental and biological constraints (Kalish 1989, Hoff \& Fuiman 1995, Chesney et al. 1998, Milton \& Chenery 2001, Elsdon \& Gillanders 2002). The objective of this study was to test the effects of temperature, salinity, and water elemental composition on the incorporation of $\mathrm{Mg}, \mathrm{Mn}$, and $\mathrm{Ba}$ in late larval/juvenile spot Leiostomus xanthurus otoliths under controlled conditions in the laboratory. Spot spawn in marine water and juveniles inhabit low salinity estuaries, so the species experiences a wide range of temperature, salinity, and water chemistry during its early life history. It may, therefore, be possible to retrospectively identify water mass residency of individual spot if temperature and salinity induce consistent and predictable changes in otolith chemistry.

\section{MATERIALS AND METHODS}

Spot Leiostomus xanthurus were hatched on 10 December 1999 at the NOAA, National Ocean Service, Center for Coastal Fisheries and Habitat Research in Beaufort, North Carolina, USA, and reared at $34 \%$ salinity and $20^{\circ} \mathrm{C}$ in a common tank in natural seawater for $42 \mathrm{~d}$. At that time they were randomly distributed among 24 acid-washed 201 highdensity polyethylene tanks at a density of 2 fish $\mathrm{l}^{-1}$. Experimental tanks were randomly assigned 4 temperature treatments $\left(17,20,23\right.$, and $\left.26^{\circ} \mathrm{C}\right)$ and 2 salinity treatments (15 and $25 \%$ ). For each treatment combination, 3 replicate tanks were used (24 tanks in total). The ambient temperature in the room was maintained at $16^{\circ} \mathrm{C}$ and electric aquarium heaters were used to regulate temperatures within individual tanks. Artificial seawater (Instant Ocean ${ }^{\circledR}$ ) was dissolved in deionized water to regulate salinity. Before initiating the experiment, fish were gradually acclimated to the temperature and salinity treatments for a week to ensure high survival. The light:dark cycle was 12:12 $\mathrm{h}$ for the duration of the experiment. Fish were fed an artificial diet (Golden Pearls, 300 to 500 and 500 to $800 \mu \mathrm{m}$, Brine Shrimp Direct) twice daily ad libitum. To maintain water quality and salinity, water was changed at $50 \%$ volume daily.

Water temperature was measured and recorded daily (Table 1). Every third day, water samples from each tank were collected, filtered through $0.22 \mu \mathrm{m}$ cellulose nitrate membrane filters, acidified with $40 \%$ trace-metal grade $\mathrm{HCl}$ to $\mathrm{pH} 2$, and then stored frozen for subsequent analysis.

All surviving fish after terminating the experiment (42 d) were measured (17.3 to $38.0 \mathrm{~mm} \mathrm{SL}$ ) and stored frozen in individual plastic bags. Sagittal otolith pairs were removed from the fish and adhering tissue was removed with acid-washed glass probes in a clean room. Otoliths were cleaned ultrasonically in Milli-Q water for $7 \mathrm{~min}$, triple rinsed with ultrapure $\mathrm{H}_{2} \mathrm{O}_{2}$ (Ultrex, J. T. Baker), and washed with 3 sequential rinses of Milli-Q water. Otolith pairs were placed on 
Table 1. Leiostomus xanthurus. Summary of mean water temperature (Temp., ${ }^{\circ} \mathrm{C}_{1} \pm$ standard deviation [SD]), salinity treatment (Sal., \%o), dissolved $\mathrm{Mg} / \mathrm{Ca}\left(\mathrm{mol} \mathrm{mol}^{-1}, \pm \mathrm{SD}\right), \mathrm{Mn} / \mathrm{Ca}\left(\mu \mathrm{mol} \mathrm{mol}^{-1}, \pm \mathrm{SD}\right)$ and $\mathrm{Ba} / \mathrm{Ca}\left(\mu \mathrm{mol} \mathrm{mol}{ }^{-1}, \pm \mathrm{SD}\right)$ levels, individual element concentrations for $\mathrm{Mg}$

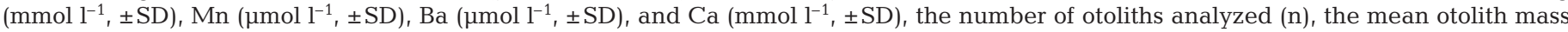

$(\mathrm{OM}, \mathrm{mg}, \pm \mathrm{SD})$ and somatic growth rate $\left(\mathrm{GR}, \mathrm{mm} \mathrm{d}^{-1}, \pm \mathrm{SD}\right)$ within each of the 24 individual tanks during the course of the experiment

\begin{tabular}{|c|c|c|c|c|c|c|c|c|c|c|c|c|}
\hline Tan & k Temp. & Sal. & {$[\mathrm{Mg}]$} & {$[\mathrm{Mn}]$} & {$[\mathrm{Ba}]$} & [Ca] & {$[\mathrm{Mg} / \mathrm{Ca}]$} & [Mn/Ca] & {$[\mathrm{Ba} / \mathrm{Ca}]$} & $\mathrm{n}$ & $\mathrm{OM}$ & GR \\
\hline 9 & $17.5(0.7)$ & 15 & $0.65(0.08)$ & $37.30(12.01)$ & $14.13(1.57)$ & $0.23(0.03)$ & $4.57(0.17)$ & $115.86(27.70)$ & $17.72(0.81)$ & 7 & $0.93(0.23)$ & $0.47(0.11)$ \\
\hline 11 & $18.1(0.7)$ & 15 & $0.58(0.03)$ & $30.05(15.24)$ & $9.71(6.82)$ & $0.20(0.10)$ & $4.79(0.11)$ & & & 7 & & \\
\hline 20 & $18.5(0.7)$ & 15 & $0.59(0.01)$ & $33.86(4.63)$ & $12.85(2.38)$ & $0.19(0$. & & 33.26 (22.96) & & 8 & & \\
\hline 24 & $20.1(0.9)$ & 15 & $0.56(0.02)$ & 29.91 (13.81) & $11.73(5$. & $0.20(0.1$ & & 115.87 (18.09) & $17.76(1.75)$ & $\varepsilon$ & 0.72 & \\
\hline 5 & $20.8(0.4)$ & 15 & $0.62(0.01)$ & $30.33(7.49)$ & $13.26(3.12)$ & $0.20(0.05)$ & $5.03(0.5$ & 110.52 & $19.12(1.79)$ & 7 & 0.98 & $0.45(0.12)$ \\
\hline 18 & $21.2(1.3)$ & 15 & $0.71(0.05)$ & 39.03 (12.98) & $15.28(1.5$ & $0.25(0.02)$ & 4.63( & $111.38(28.8$ & $17.63(1.26)$ & & 0.89 & $0.42(0$ \\
\hline 10 & $22.7(1.8)$ & 15 & $0.58(0.08)$ & 33.13 (7.03) & 12.37 & $0.20(0.03)$ & 4.81 & $121.25(14.24)$ & 18.12 & & 1.21 & $0.52(0$ \\
\hline 21 & $23.4(1.1)$ & 15 & $0.66(0.07)$ & $32.38(4.71)$ & $16.20(4.43)$ & $0.24(0.03)$ & 4.65( & $100.47(5.48)$ & $20.18(5.48)$ & 8 & $1.12(0.27)$ & $0.48(0.09)$ \\
\hline 22 & $23.8(2.3)$ & 15 & $0.62(0.06)$ & $35.10(4.02)$ & $13.13(1.54)$ & $0.22(0.02)$ & $4.72(0.09)$ & $120.37(26.83)$ & $17.70(0.74)$ & 8 & $0.79(0.25)$ & $0.37(0.08)$ \\
\hline 4 & 26.1 (1.3) & 15 & $0.66(0.09)$ & $30.21(9.19)$ & $13.88(1.41)$ & $0.22(0.02)$ & $4.89(0.28)$ & $100.13(33.54)$ & $18.19(0.18)$ & 8 & $1.20(0.30)$ & $0.50(0.12)$ \\
\hline 14 & $26.2(1.6)$ & 15 & $0.69(0.07)$ & $28.40(2.74)$ & 14.49 (1.29) & $0.25(0.02)$ & $4.61(0.04)$ & 84.60 & $17.21(0.66)$ & 8 & $0.95(0.23)$ & $0.42(0.08)$ \\
\hline 16 & $26.8(1.2)$ & 15 & $0.61(0.15)$ & $23.76(6.78)$ & $12.94 i$ & $0.21(0.06)$ & 4.75 & (7.72) & $17.64(0.83)$ & 8 & $1.21(0.24)$ & $0.50(0.07)$ \\
\hline 1 & $17.5(0.6)$ & 25 & $0.96(0.22)$ & $45.30(10.55)$ & 16.91( & $0.33(0.08)$ & 4.76 & .66) & 15.01 & 8 & $0.62(0$ & $0.32(0$ \\
\hline 7 & $17.8(0.7)$ & 25 & $1.04(0.07)$ & 43.24 (8.67) & $12.82(10.96)$ & $0.37(0.03)$ & $4.71(0.13)$ & 1.77) & $10.01(8.51)$ & 4 & $0.80(0.18)$ & $0.31(0.07)$ \\
\hline 15 & $18.7(0.9)$ & 25 & $0.96(0.21)$ & $43.61(14.00)$ & 16.06 & $0.33(0.08)$ & 4.81 & 60) & 14.5 & 8 & 0.54 & $0.28(0$ \\
\hline 2 & $19.9(0.4)$ & 25 & $1.12(0.25)$ & 38.84 (12.01) & 19.77 & & & & 14. & 8 & 0.69 & $0.30(0.06)$ \\
\hline 8 & $20.2(0.3)$ & 25 & $1.09(0.16)$ & $52.91(31.71)$ & $20.36(3.74)$ & $0.36(0.05)$ & $4.67(0.04)$ & $109.78(64.82)$ & $16.78(2.35)$ & 8 & $0.63(0.18)$ & $0.26(0.08)$ \\
\hline 6 & $20.3(0.3)$ & 25 & $0.99(0.14)$ & $34.81(15.74)$ & $15.72(9.33)$ & $0.35(0.05)$ & $4.69(0.12)$ & 71.47 (26.89) & $13.18(7.46)$ & 8 & $0.70(0.15)$ & $0.34(0.06)$ \\
\hline 23 & $23.2(0.3)$ & 25 & $1.06(0.09)$ & $50.32(18.21)$ & $16.16(7.66)$ & $0.38(0.04)$ & $4.65(0.14)$ & & $13.04(6.60)$ & 8 & $0.94(0.34)$ & $0.43(0.14)$ \\
\hline 12 & $23.3(2.3)$ & 25 & $1.12(0.11)$ & $37.92(10.42)$ & $12.37(7.91)$ & $0.38(0.03)$ & & & & 7 & & $0.43(0.14)$ \\
\hline 13 & $23.5(2.2)$ & 25 & $1.16(0.11)$ & $39.40(1$ & $22.95(2.22)$ & $0.41(0.04)$ & & & $16.35(0.58)$ & & $0.89(0$. & \\
\hline 19 & $25.6(1.3)$ & 25 & $1.14(0.07)$ & 28.93 & $18.33(8$. & & & & 12.97 & 8 & $0.91(0.29)$ & $0.39(0.13)$ \\
\hline 3 & $25.8(2.6)$ & 25 & & & $20.11(5$. & $0.32(0.08)$ & & & 18.22 & 1 & 0.84 & 0.33 \\
\hline 17 & $26.3(0.4)$ & 25 & $1.05(0.17)$ & 30.76 (18.97) & $17.72(4.65)$ & $0.37(0.07)$ & $4.67(0.17)$ & 64.46 (44.69) & $14.31(4.14)$ & 6 & $1.06(0.26)$ & $0.44(0.10)$ \\
\hline
\end{tabular}

acid-washed glass slides to dry for $36 \mathrm{~h}$ under a class100 laminar-flow hood. After drying, otoliths were individually weighed to the nearest $10 \mu \mathrm{g}$ and transferred to individual acid-washed $1.5 \mathrm{ml}$ high-density polyethylene vials.

A maximum of 8 fish were randomly selected from each tank and their otoliths prepared for analysis by inductively coupled plasma mass spectrometry (ICPMS). If the total number of remaining fish in the tank after the experimental period was less than 8, all remaining fish were used for analyses. Otoliths were dissolved in $70 \%$ ultrapure nitric acid (Ultrex II, J. T. Baker) and the solution diluted to achieve a total dissolved solid concentration of $0.1 \mathrm{mg} \mathrm{g}^{-1}$ in $1 \% \mathrm{HNO}_{3}$. Otolith solutions were stored at $4^{\circ} \mathrm{C}$ until the ICP-MS analysis. Otolith analyses were run on a Thermo Finnigan Element ICP-MS equipped with a self-aspirating $\left(50 \mu \mathrm{min}^{-1}\right)$ PFA nebulizer and a dual-inlet quartz spray chamber. The method measured ${ }^{25} \mathrm{Mg},{ }^{48} \mathrm{Ca}$, ${ }^{55} \mathrm{Mn}$, and ${ }^{138} \mathrm{Ba}$ in low resolution $(\mathrm{R}=300)$ during a 2 min acquisition time.

Quantification of metal/calcium (Me/Ca) ratios followed the procedure outlined by Rosenthal et al. (1999). All samples were standardized to a dissolved solution $\left(0.1 \mathrm{mg} \mathrm{g}^{-1}\right)$ of an otolith reference powder with certified $\mathrm{Me} / \mathrm{Ca}$ ratios of $89.25 \mu \mathrm{mol} \mathrm{mol}{ }^{-1}$ for $\mathrm{Mg} / \mathrm{Ca}, 0.257 \mu \mathrm{mol} \mathrm{mol}{ }^{-1}$ for $\mathrm{Mn} / \mathrm{Ca}$, and $2.174 \mu \mathrm{mol}$ $\mathrm{mol}^{-1}$ for Ba/Ca (Yoshinaga et al. 2000). The matrix of the standard was therefore matched to the dissolved Ca levels in the samples. Detection limits were calculated as $3 \sigma$ values of $1 \% \mathrm{HNO}_{3}$ sample blanks $(\mathrm{n}=37)$ that were run throughout the analyses. These limits were $0.2 \%$ of the average sample intensity for ${ }^{25} \mathrm{Mg}$, $0.05 \%$ for ${ }^{48} \mathrm{Ca}, 0.3 \%$ for ${ }^{55} \mathrm{Mn}$, and $0.1 \%$ for ${ }^{138} \mathrm{Ba}$. An internal laboratory standard was run after each reference sample to estimate precision of the $\mathrm{Me} / \mathrm{Ca}$ method. The reference material was then treated as an unknown, and Me/Ca values determined as for individual samples above. Measured precision (\% relative standard deviation [RSD], $\mathrm{n}=37$ ) of the $\mathrm{Me} / \mathrm{Ca}$ method was $2.7 \%$ for $\mathrm{Mg} / \mathrm{Ca}, 2.8 \%$ for $\mathrm{Mn} / \mathrm{Ca}$ and $0.5 \%$ for $\mathrm{Ba} / \mathrm{Ca}$.

Water samples collected during the experiment were also analyzed using ICP-MS. Every other week, 4 samples were analyzed from each tank. All samples were spiked with an internal elemental standard of Indium (to $4.5 \mu \mathrm{g} \mathrm{g}^{-1}$ ). The solutions were then aspirated into a Thermo Finnigan Element 2 ICP-MS, via a self-aspirat-

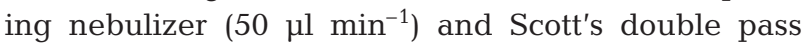
spray chamber. Due to the presence of significant interferences on most of the Ca isotopes, ${ }^{44} \mathrm{Ca}^{2}{ }^{25} \mathrm{Mg}$, ${ }^{55} \mathrm{Mn},{ }^{137} \mathrm{Ba}$, and ${ }^{115} \mathrm{In}$ were measured in medium resolution (nominal $\mathrm{R}=4500$ ). The means of 4 water samples from each tank were used in all subsequent 
analyses. A seawater reference material (High Purity Standards, seawater CRM [certified reference material]) was used to estimate precision of the water measurements, including $\mathrm{Ca}, \mathrm{Mg}, \mathrm{Mn}$, and Ba values. Our estimates of precision for element concentrations in the seawater CRM were $1.4 \%$ RSD for $\mathrm{Ca}, 1.4 \%$ RSD for $\mathrm{Mg}, 2.7 \%$ RSD for Mn, and $1.7 \%$ RSD for Ba $(\mathrm{n}=8)$.

Partition coefficients $\left(D_{\mathrm{Me}}\right)$ were calculated by dividing the metal/calcium (Me/Ca) ratio measured in an otolith by the mean Me/Ca ratio measured in the treatment tank water (Morse \& Bender 1990). Otolith $\mathrm{Me} / \mathrm{Ca}$ values from individual fish were averaged within tanks, and then the 3 tank averages were used as replicates for each of the 8 treatments.

Otolith mass was used as a proxy for otolith precipitation rate. Because all fish were the same age, otolith precipitation rate was greater in individuals with larger otoliths. Analysis of covariance (ANCOVA) was used to test the influence of otolith precipitation rate on each $D_{\mathrm{Me}}$, using otolith mass as a covariate and temperature and salinity as independent categorical variables. Using Pearson correlations, the influence of otolith precipitation rate was also tested by correlating otolith mass with $D_{\mathrm{Me}}$ within each of the 23 tanks of sufficient sample sizes. This provided a test of rate effects on $D_{\mathrm{Me}}$ because all fish within the tanks experienced identical environmental conditions (Bath et al. 2000, Martin et al. 2004).

Change in standard length (SL) over the course of the experiment was used as a proxy for somatic growth rate. Individual growth rates were calculated as the difference between the mean SL of pooled fish at the beginning of the experiment and the SL of individual fish at the end of the experiment divided by the number of experiment days. The means of fish growth rates were calculated for individual tanks. ANCOVAs were used to test the influence of somatic growth rate on each $D_{\mathrm{Me}}$ using growth rate as a covariate and temperature and salinity as independent categorical variables. Finally, using Pearson correlations, the influence of somatic growth rate on otolith precipitation rate was tested by correlating growth rate with $D_{\mathrm{Me}}$ within each of the 23 tanks with sufficient sample sizes.

Two-way analysis of variance (ANOVA) was used to test for significant differences in $[\mathrm{Me} / \mathrm{Ca}]_{\text {water, }}$ $[\mathrm{Me} / \mathrm{Ca}]_{\text {otolith, }}$ and $D_{\mathrm{Me}}$ among temperature and salinity treatments. Salinity and temperature were treated as independent categorical variables, and $[\mathrm{Me} / \mathrm{Ca}]_{\text {water }}$, $[\mathrm{Me} / \mathrm{Ca}]_{\text {otolith }}$ and $D_{\mathrm{Me}}$ as dependent variables in the analyses. The assumptions of ANOVA were met: the data were normally distributed and variances were homogeneous among factor levels. To control for experiment-wise error, the critical p-value $(\alpha=0.05)$ was adjusted $(\alpha=0.017)$ to account for the 3 individual ANOVAs performed.

\section{RESULTS}

\section{Water chemistry}

Elemental concentrations in the tank water were significantly different between salinity treatments, but not among temperatures. As expected, $\mathrm{Ca}, \mathrm{Mg}, \mathrm{Mn}$, and $\mathrm{Ba}$ concentrations in the water were higher at $25 \%$ than at $15 \%$ o $\left([\mathrm{Ca}]_{\text {water }}:|t|_{0.05,(2), 22}=14.62, \mathrm{p}=0.000\right.$; $[\mathrm{Mg}]_{\text {water }}:|t|_{0.05,(2), 22}=16.57, \mathrm{p}=0.000 ;[\mathrm{Mn}]_{\text {water }}$ : $|t|_{0.05,(2), 22}=2.99, \mathrm{p}=0.003 ;[\mathrm{Ba}]_{\text {water }}:|t|_{0.05,(2), 22}=4.03$, $\mathrm{p}=0.000) .[\mathrm{Mg} / \mathrm{Ca}]_{\text {water }}$ was not significantly different between salinity treatments $(F=0.565, \mathrm{p}=0.463, \mathrm{n}=$ 24) or temperature treatments $(F=0.339, \mathrm{p}=0.797, \mathrm{n}=$ $24)$. However, $[\mathrm{Mn} / \mathrm{Ca}]_{\text {water }}$ values were significantly higher at $15 \%$ than at $25 \%(F=32.325, \mathrm{p}=0.000, \mathrm{n}=$ $24)$, and differed significantly among temperature treatments $(F=6.648, \mathrm{p}=0.004, \mathrm{n}=24)$. Similarly, $[\mathrm{Ba} / \mathrm{Ca}]_{\text {water }}$ values were also significantly higher at $15 \%$ than at $25 \%$, $(F=19.282, \mathrm{p}=0.000, \mathrm{n}=24)$, but not among temperature treatments $(F=0.366, \mathrm{p}=$ $0.779, \mathrm{n}=24$ ). Lower absolute $\mathrm{Mn}, \mathrm{Ba}$, and proportionately lower Ca concentrations in 15\% salinity tanks led to higher $\mathrm{Mn} / \mathrm{Ca}$ and $\mathrm{Ba} / \mathrm{Ca}$ ratios in the low salinity treatment (Table 1, Fig. 1) presumably because Mn/ $\mathrm{Ca}$ and $\mathrm{Ba} / \mathrm{Ca}$ ratios were higher in the deionized water source than in the $25 \%$ salinity artificial seawater.

\section{Otolith $[\mathrm{Me} / \mathrm{Ca}]$ and $\mathrm{Me} / \mathrm{Ca}$ partition coefficients}

Leiostomus xanthurus were initially reared in a single large tank before being randomly assigned and transferred to smaller tanks for the duration of the experiment. We assumed that conditions during the initial rearing period had little effect on the resultant otolith chemistry of the experimental fish because otoliths from these fish averaged less than $50 \mu \mathrm{g}$ compared to a mean value of $890 \mu \mathrm{g}$ for otoliths from fish at the end of the experiment.

The $\mathrm{Mg} / \mathrm{Ca}$ values in the Leiostomus xanthurus otoliths $(\mathrm{n}=173)$ ranged from 0.676 to $4.74 \mathrm{mmol} \mathrm{mol}^{-1}$, with an overall mean of $1.80 \mathrm{mmol} \mathrm{mol}{ }^{-1}$. Magnesium partition coefficients $\left(D_{\mathrm{Mg}}\right)$ were considerably less than 1 (among treatment mean $=0.00038$, range 0.00014 to 0.001 ), suggesting that Mg ions were actively excluded from the otolith either during movement across membranes or at the site of aragonite precipitation in the endolymph. We found no significant effects of temperature or salinity on $\mathrm{Mg} / \mathrm{Ca}$ ratios, and a non-significant interaction (Table 2, Fig. 2). $D_{\mathrm{Mg}}$ showed a similar pattern to the $\mathrm{Mg} / \mathrm{Ca}$ ratios, with no significant effects of temperature or salinity, and an insignificant interaction (Table 3, Fig. 3). 

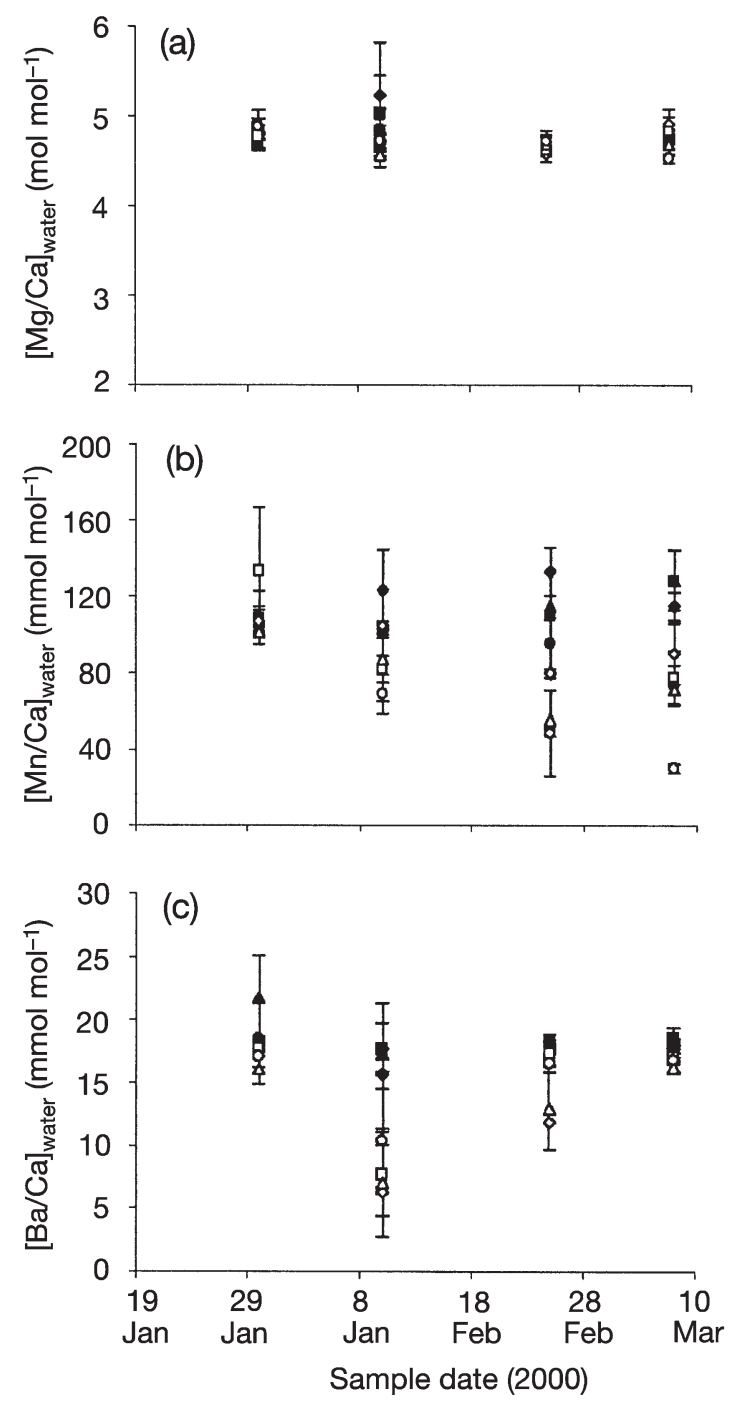

Fig. 1. Calculated metal/calcium ratios in the tank water (a) $\mathrm{Mg} / \mathrm{Ca}$, (b) $\mathrm{Mn} / \mathrm{Ca}$, and (c) $\mathrm{Ba} / \mathrm{Ca}$ concentrations $\pm \mathrm{SE}$ by sample date for the duration of the experiment. Solid symbols represent the $15 \%$ salinity treatment tanks and the open symbols represent the $25 \%$ salinity treatment tanks. Each of the 4 temperature treatments is represented by a different symbol: $17^{\circ} \mathrm{C}(\bullet), 20^{\circ} \mathrm{C}(\bullet), 23^{\circ} \mathrm{C}(\bullet)$, and $26^{\circ} \mathrm{C}(\bullet)$

Manganese values ([Mn/Ca $\left.]_{\text {otolith }}\right)$ in the Leiostomus xanthurus otoliths varied by more than an order of magnitude (6.32 to $101.01 \mu \mathrm{mol} \mathrm{mol}^{-1}$ ) with an overall mean of $18.055 \mu \mathrm{mol} \mathrm{mol}{ }^{-1}$. Estimates of the $\mathrm{Mn} / \mathrm{Ca}$ partition coefficient $\left(D_{\mathrm{Mn}}\right)$ varied over a similar range (0.055 to 0.92$)$, with an overall mean of 0.196 . We found no significant effects of temperature, salinity, or their interaction on $[\mathrm{Mn} / \mathrm{Ca}]_{\text {otolith }}$ (Table 2, Fig. 2). However, among-tank variation in water chemistry clearly influenced our results because $D_{\mathrm{Mn}}$ were significantly affected by both temperature and salinity,
Table 2. Leiostomus xanthurus. Results of 2-way ANOVA testing the effect of temperature (T), salinity (S) and the temperature-salinity interaction $(\mathrm{T} \times \mathrm{S})$ on $\log _{\mathrm{e}}$-transformed $\mathrm{Mg} / \mathrm{Ca}, \mathrm{Mn} / \mathrm{Ca}$ and $\mathrm{Ba} / \mathrm{Ca}$ ratios in the otoliths of juvenile L. xanthurus. $\mathrm{p}$ is not signifiicant for all entries

\begin{tabular}{|ccccc|}
\hline & Factor & df & MS & $F$ \\
\hline$[\mathrm{Mg} / \mathrm{Ca}]_{\text {otolith }}$ & $\mathrm{T}$ & 3 & 483322.15 & 3.660 \\
& $\mathrm{~S}$ & 1 & 361225.57 & 2.736 \\
& $\mathrm{~T} \times \mathrm{S}$ & 3 & 47976.76 & 0.363 \\
{$[\mathrm{Mn} / \mathrm{Ca}]_{\text {otolith }}$} & $\mathrm{T}$ & 3 & 33.497 & 1.766 \\
& $\mathrm{~S}$ & 1 & 5.484 & 0.289 \\
& $\mathrm{~T} \times \mathrm{S}$ & 3 & 33.343 & 1.758 \\
{$[\mathrm{Ba} / \mathrm{Ca}]_{\text {otolith }}$} & $\mathrm{T}$ & 3 & 2.567 & 0.717 \\
& $\mathrm{~S}$ & 1 & 12.285 & 3.431 \\
& $\mathrm{~T} \times \mathrm{S}$ & 3 & 2.273 & 0.635 \\
& & & & \\
\hline
\end{tabular}

and the interaction term (Table 3). The significant interaction was generated by the observation that $D_{\mathrm{Mn}}$ increased with temperature in the $15 \%$ salinity treatment but not in the $25 \%$ treatment.

The $\mathrm{Ba} / \mathrm{Ca}$ ratios in Leiostomus xanthurus otoliths ranged from 2.02 to $15.8 \mu \mathrm{mol} \mathrm{mol}^{-1}$, with an overall mean of $6.01 \mu \mathrm{mol} \mathrm{mol}{ }^{-1}$. Barium partition coefficients $\left(D_{\mathrm{Ba}}\right)$ were closer to equilibrium with ambient water than either $D_{\mathrm{Mn}}$ or $D_{\mathrm{Mg}}$, with an overall mean of 0.37 and a range of 0.11 to 1.23 . Temperature, salinity, and the temperature-salinity interaction had no significant effect on $[\mathrm{Ba} / \mathrm{Ca}]_{\text {otolith }}$ (Table 2, Fig. 2). As with $\mathrm{Mn}$, however, we attributed at least some of the variability in $[\mathrm{Ba} / \mathrm{Ca}]_{\text {otolith }}$ to among-tank variability in $[\mathrm{Ba} / \mathrm{Ca}]_{\text {water }}$ within treatments. We found a significant effect of salinity on $D_{\mathrm{Ba}}$, with non-significant temperature effect, and non-significant interaction between the 2 factors (Table 3 ). $D_{\mathrm{Ba}}$ were higher at $15 \%$ o than at $25 \%$ (Fig. 3).

Table 3. Leiostomus xanthurus. Results of 2-way ANOVA testing the effect of temperature $(\mathrm{T})$, salinity $(\mathrm{S})$ and the temperature-salinity interaction $(\mathrm{T} \times \mathrm{S})$ on $\log _{\mathrm{e}}$-transformed $\mathrm{Mg}$, $\mathrm{Mn}$, and Ba partition coefficients $\left(D_{\mathrm{Mg}}, D_{\mathrm{Mn}}\right.$ and $\left.D_{\mathrm{Ba}}\right)$ in the otoliths of juvenile $L$. xanthurus (ns = non-significant, ${ }^{*}$ significant at $\alpha=0.017$ )

\begin{tabular}{|cccccc|}
\hline & Factor & df & MS & $F$ & $\mathrm{p}$ \\
\hline$D_{\mathrm{Mg}}$ & $\mathrm{T}$ & 3 & 0.019 & 3.584 & $\mathrm{~ns}$ \\
& $\mathrm{~S}$ & 1 & 0.018 & 3.452 & $\mathrm{~ns}$ \\
& $\mathrm{~T} \times \mathrm{S}$ & 3 & 0.002 & 0.450 & $\mathrm{~ns}$ \\
$D_{\mathrm{Mn}}$ & $\mathrm{T}$ & 3 & 0.020 & 13.617 & ${ }^{*}$ \\
& $\mathrm{~S}$ & 1 & 0.020 & 13.316 & ${ }^{*}$ \\
& $\mathrm{~T} \times \mathrm{S}$ & 3 & 0.008 & 5.187 & ${ }^{*}$ \\
$D_{\mathrm{Ba}}$ & $\mathrm{T}$ & 3 & 0.021 & 0.640 & $\mathrm{~ns}$ \\
& $\mathrm{~S}$ & 1 & 0.267 & 8.158 & ${ }^{*}$ \\
& $\mathrm{~T} \times \mathrm{S}$ & 3 & 0.021 & 0.648 & $\mathrm{~ns}$ \\
& & & & & \\
\hline
\end{tabular}




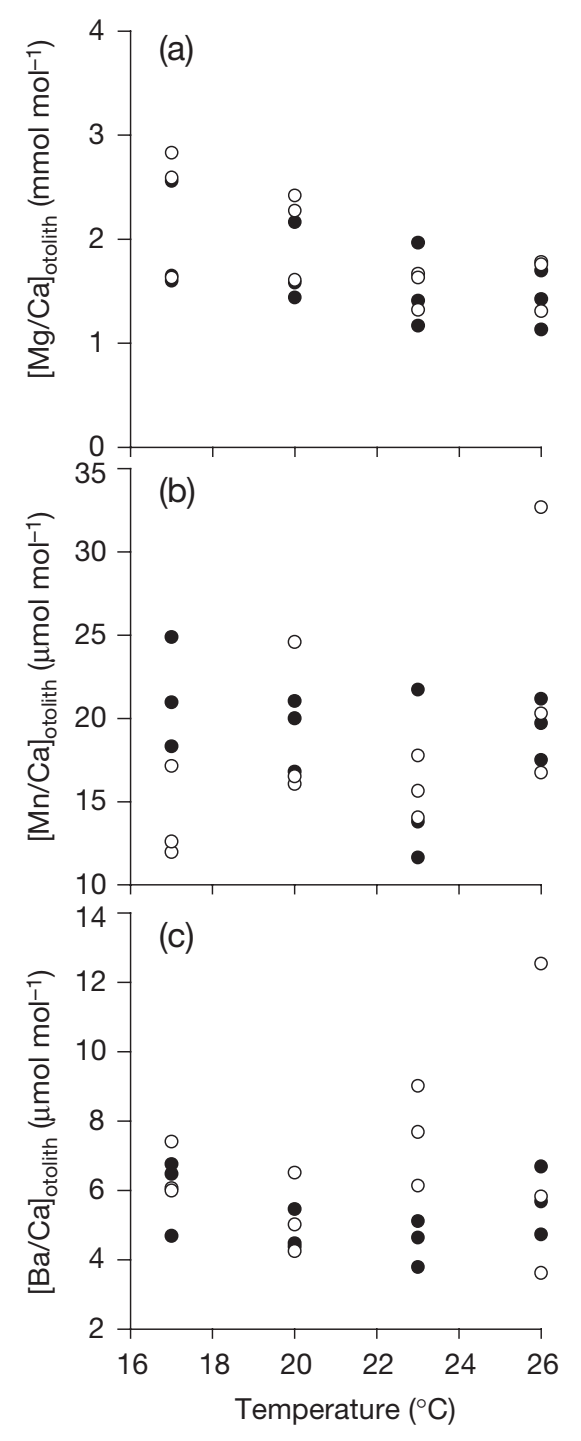

Fig. 2. Leiostomus xanthurus. (a) $\mathrm{Mg} / \mathrm{Ca}$, (b) $\mathrm{Mn} / \mathrm{Ca}$, and (c) $\mathrm{Ba} / \mathrm{Ca}$ ratios in otoliths of laboratory-reared L. xanthurus as a function of tank temperatures at 2 salinity levels, $15 \%$ o (•) and $25 \%$ o $(0)$

\section{Biomineralization and growth rate effects}

We used otolith mass as a proxy for otolith precipitation rates to examine potential effects of calcification rate on otolith chemistry using ANCOVA (Table 4). Otolith mass had a significant effect on $D_{\mathrm{Mg}}(F=56.65$, $\mathrm{p}=0.000, \mathrm{n}=24)$, no significant effect on $D_{\mathrm{Mn}}(F=0.06$, $\mathrm{p}=0.81, \mathrm{n}=24)$, and no significant effect on $D_{\mathrm{Ba}}(F=$ $0.57, \mathrm{p}=0.46, \mathrm{n}=24$ ). However, it is possible that rate effects were aliased to some degree by significant variability in $D_{\mathrm{Me}}$ as a function of temperature and salinity. We therefore ran Pearson correlations between otolith mass and $D_{\mathrm{Me}}$ for each of 23 tanks, because individual fish within a tank had experienced identical condi- tions. A total of 13 out of 23 correlations between otolith mass and $D_{\mathrm{Mg}}$ were negative, and 4 out of 23 correlations were significant after applying the Bonferroni correction for multiple tests. A total of 15 out of 23 correlations were negative for $D_{\mathrm{Mn}}$, but none of the 23 correlations were significant after the appropriate Bonferroni correction. Similarly, although a total of 10 out of 23 correlations between $D_{\mathrm{Ba}}$ and otolith mass were negative, only 3 of the 23 within-tank correlations were statistically significant.

Somatic growth rates of Leiostomus xanthurus varied significantly with temperature $(F=4.52, \mathrm{p}=0.019$,

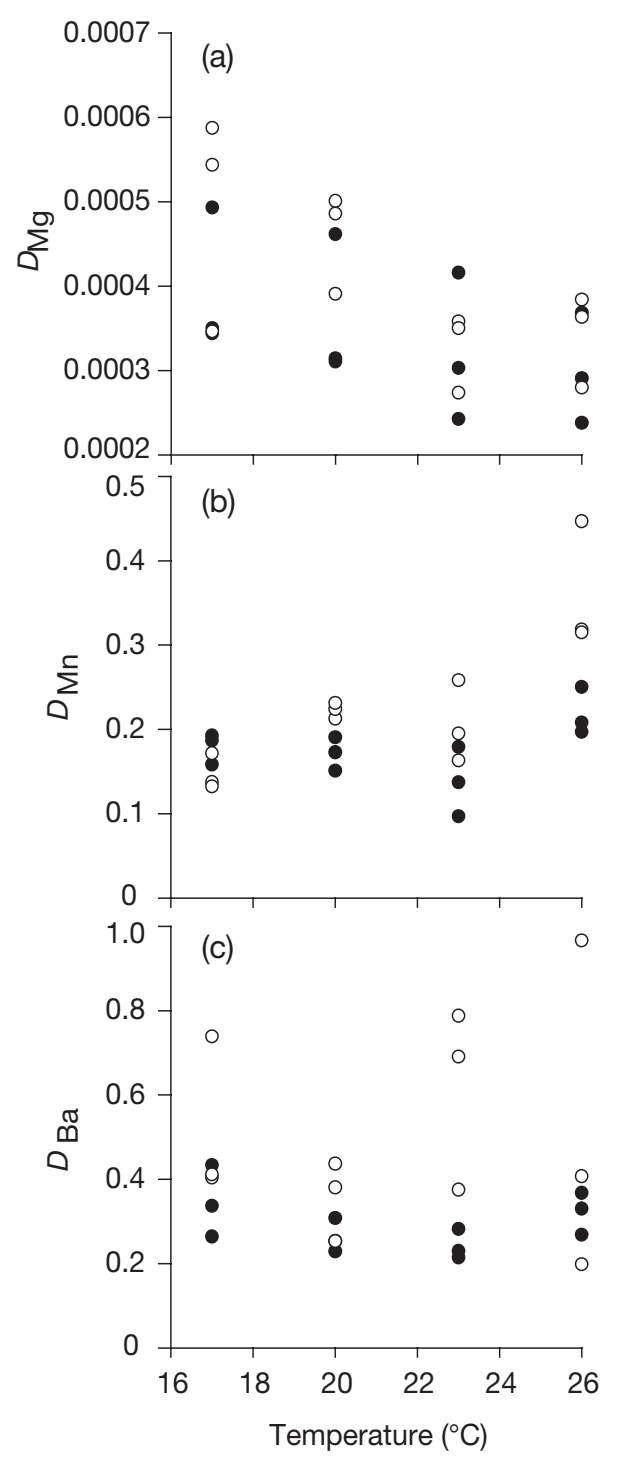

Fig. 3. Leiostomus xanthurus. (a) Mg/Ca partition coefficients $\left(D_{\mathrm{Mg}}\right)$, (b) $\mathrm{Mn} / \mathrm{Ca}$ partition coefficients $\left(D_{\mathrm{Mn}}\right)$, and (c) $\mathrm{Ba} / \mathrm{Ca}$ partition coefficients $\left(D_{\mathrm{Ba}}\right)$ for otoliths of laboratory-reared $L$. xanthurus as a function of tank temperatures at 2 salinity levels, 15\% (•) and 25\% (०) 


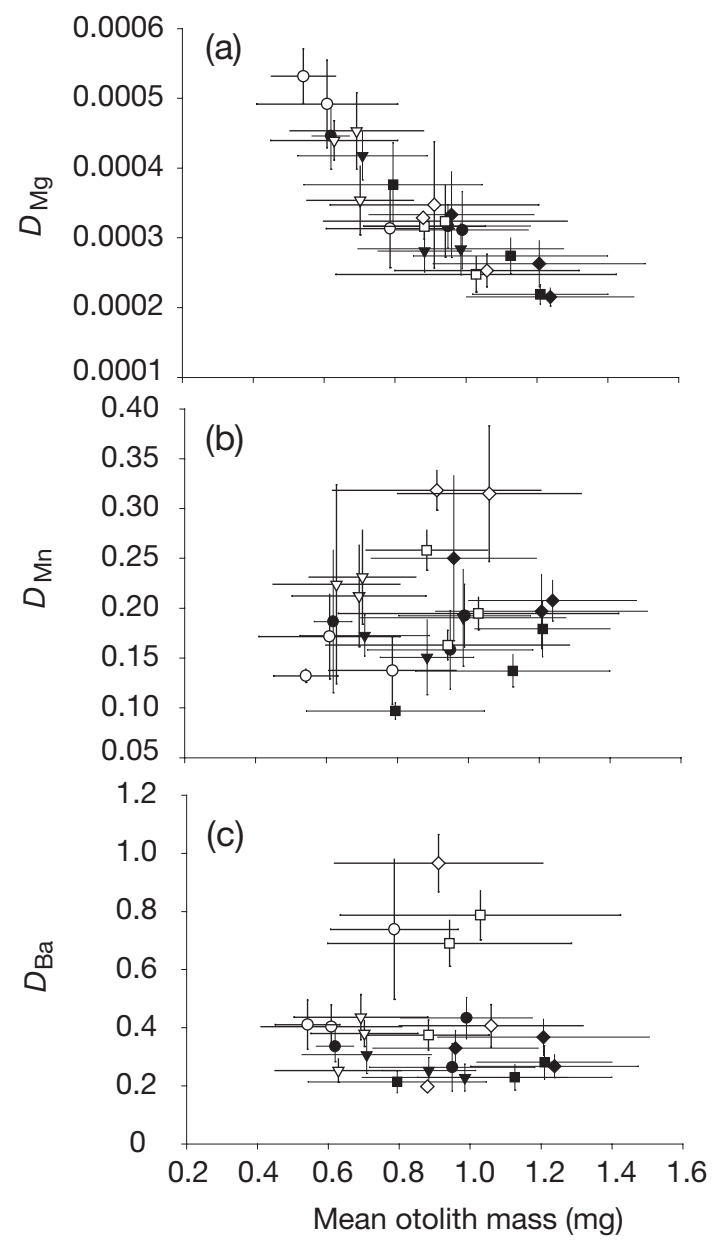

Fig. 4. Leiostomus xanthurus. (a) Mg/Ca partition coefficients $\left(D_{\mathrm{Mg}}\right)$, (b) $\mathrm{Mn} / \mathrm{Ca}$ partition coefficients $\left(D_{\mathrm{Mn}}\right)$, and (c) $\mathrm{Ba} / \mathrm{Ca}$ partition coefficients $\left(D_{\mathrm{Ba}}\right)$ for otoliths of laboratory-reared $L$. xanthurus as a function of otolith mass within each tank. Each of the 4 temperature treatments is represented by a different symbol: $17^{\circ} \mathrm{C}(\bullet), 20^{\circ} \mathrm{C}(\boldsymbol{\nabla}), 23^{\circ} \mathrm{C}(\bullet)$, and $26^{\circ} \mathrm{C}(\bullet)$ at 2 salinity levels, 15\%o (solid) and 25\%o (open)

$\mathrm{n}=24)$, and salinity $(F=11.43, \mathrm{p}=0.004, \mathrm{n}=24)$. Growth rates also influenced $D_{\mathrm{Mg}}(F=18.14, \mathrm{p}=$ $0.001, \mathrm{n}=24)$, but had no detectable effect on either $D_{\mathrm{Mn}}(F=0.08, \mathrm{p}=0.79, \mathrm{n}=24)$ or $D_{\mathrm{Ba}}(F=0.02, \mathrm{p}=$ $0.90, \mathrm{n}=24$ ) (Fig. 4). Within tank correlations between growth rate and $D_{\mathrm{Mg}}$ found that 13 out of 23 correlations were negative, and 5 out of 23 correlations were significant after Bonferroni adjustment. Correlations between growth rate and $D_{\mathrm{Mn}}$ demonstrated that 13 out of 23 correlations were negative, although none of the 23 correlations were statistically significant. Finally, 12 out of 23 correlations between $D_{\mathrm{Ba}}$ and growth rate within each of the tanks were negative, and 5 of the 23 correlations were significant after Bonferroni adjustment.

\section{DISCUSSION}

Numerous environmental and biological effects are likely to influence the elemental composition of fish otoliths. Many of these effects are also likely to covary. For instance, fish growth rate, otolith precipitation rate, and temperature are all likely to be positively correlated in the field collections. We reared fish in the laboratory under controlled environmental conditions to examine temperature and salinity effects on the incorporation of $\mathrm{Mg}, \mathrm{Mn}$, and $\mathrm{Ba}$ in fish otoliths while minimizing other influences on otolith chemistry. All fish used in the experiment were from the same brood stock and were the same age, therefore limiting possible genetic or ontogenetic effects on otolith elemental incorporation. Diets among treatments were identical, thereby eliminating the effect of food on otolith elemental incorporation. The elemental composition of the water was monitored throughout the experiment, allowing us to account for significant differences in water chemistry among treatments. Therefore, we were able to test the effects of temperature and salinity on the elemental composition of otoliths without the confounding effects of genetics, ontogeny, diet, or water compositional differences.

\section{Water chemistry}

$\mathrm{Mg} / \mathrm{Ca}$ ratios were relatively constant among all treatment tanks throughout the experiment, with no significant difference among temperature and salinity treatments. There was greater variation in $\mathrm{Mn} / \mathrm{Ca}$ and $\mathrm{Ba} / \mathrm{Ca}$ among treatments, despite our attempts to maintain constant elemental ratios in all the tanks. Both $\mathrm{Mn} / \mathrm{Ca}$ and $\mathrm{Ba} / \mathrm{Ca}$ were significantly higher at $15 \%$ than at $25 \%$. The water for the lower salinity treatment was a dilution of the higher salinity water, and therefore both $\mathrm{Mn} / \mathrm{Ca}$ and $\mathrm{Ba} / \mathrm{Ca}$ were higher in the deionized water used to generate the $15 \%$ treatment than in the artificial seawater at $25 \%$. A similar result was also noted for Sr/Ca ratios in the same experiment (Martin et al. 2004). Nonetheless, by collecting water samples at regular intervals throughout the experiment we were able to quantify the water chemistry experienced by fish in each of the tanks and therefore account for any variability in water elemental composition within tanks throughout the experiment by calculating partition coefficients (Morse \& Bender 1990).

\section{Mg partition coefficients}

Several studies have suggested that $\mathrm{Mg} / \mathrm{Ca}$ ratios in the aragonitic skeletons of corals (Mitsuguchi et al. 
1996, 2003) and mollusk shells (Crick \& Ottensman 1983, Vander Putten et al. 2000) may vary with temperature. Magnesium thermometry is more established in calcitic skeletons of foraminifera (Lea et al. 1999, Elderfield \& Ganssen 2000, Rosenthal \& Lohmann 2002) where, as with coral aragonite, $D_{\mathrm{Mg}}$ is positively correlated with temperature. Although $D_{\mathrm{Mg}}$ consistently declined with increasing temperature, the effect of temperature was not significant $(p=0.037 ; \alpha=$ Bonferroni corrected 0.017). Because $D_{\mathrm{Me}}$ in otoliths are considerably lower than those of aragonitic coral skeletons, we suspect that there is considerably more biological control over $\mathrm{Mg} / \mathrm{Ca}$ ratios in fish otoliths than in the skeletons of hermatypic corals. It will, therefore, likely be difficult to reconstruct temperature profiles based on $\mathrm{Mg} / \mathrm{Ca}$ ratios in otoliths.

\section{Mn partition coefficients}

We found evidence of complex interactions between otolith $D_{\mathrm{Mn}}$ temperature, and salinity. Specifically, salinity appeared to influence $D_{\mathrm{Mn}}$ only at the highest temperature in our experiment. At least some of the variability in $[\mathrm{Mn} / \mathrm{Ca}]_{\text {otolith }}$ may have been due to our inability to maintain constant $[\mathrm{Mn} / \mathrm{Ca}]_{\text {water }}$ in the individual tanks. Dissolved Mn is rapidly oxidized in estuarine waters, aided by microbial catalysis which plays a dominant role in the scavenging of Mn onto particles in the aquatic environment (Sunda \& Huntsman 1987, von Langen et al. 1997, Klinkhammer \& McManus 2001). We suspect that microbial-aided oxidation was also occurring in the experimental tanks. Bacterial growth was observed in the tanks, even though water was changed daily $(50 \%)$ and solid particles were removed by siphoning. It was therefore possible that bacteria served as catalysts forming manganese oxides, which precipitated out of solution, contributing to unstable $\mathrm{Mn} / \mathrm{Ca}$ concentrations in the tanks over time.

It has proved difficult to ascertain any correlation between $[\mathrm{Mn} / \mathrm{Ca}]_{\text {otolith }}$ and $[\mathrm{Mn} / \mathrm{Ca}]_{\text {water }}$ even under laboratory conditions. Elsdon \& Gillanders (2002) found no effect of either temperature or salinity on $\mathrm{Mn} / \mathrm{Ca}$ ratios in the otoliths of juvenile black bream Acanthopagus butcheri. More tellingly, in a later study the researchers were unable to detect any correlation between $[\mathrm{Mn} / \mathrm{Ca}]_{\text {otolith }}$ and $[\mathrm{Mn} / \mathrm{Ca}]_{\text {water }}$ in an experiment in which individual tanks were spiked with $\mathrm{Mn}$ up to 16 times above ambient concentrations (Elsdon \& Gillanders 2003). The results were somewhat surprising, as several authors have found that Mn was a useful element when attempting to discriminate among fish from different geographic locations based on otolith geochemistry (Thorrold et al. 1998a,b, Rooker et al. 2001, 2003). We suggest, however, that it is prema- ture to ignore the effect of water chemistry on $\mathrm{Mn} / \mathrm{Ca}$ ratios in otoliths. $D_{\mathrm{Mn}}$ certainly explained more variation among treatments in our experiment than did $[\mathrm{Mn} / \mathrm{Ca}]_{\text {otolith }}$. Nonetheless, more experimentation is clearly required before we obtain a mechanistic explanation of $\mathrm{Mn} / \mathrm{Ca}$ variations in fish otoliths.

\section{Ba partition coefficients}

All studies to date have found that $\mathrm{Ba} / \mathrm{Ca}$ ratios in otoliths accurately reflect dissolved Ba levels in the environment (Bath et al. 2000, Milton \& Chenery 2001, Elsdon \& Gillanders 2003). Effects of temperature and salinity on $D_{\mathrm{Ba}}$ have, however, been more variable when tested. We found that salinity but not temperature affected $D_{\mathrm{Ba}}$ in larval spot otoliths. Bath et al. (2000) also found that temperature had no effect on $D_{\text {Ва }}$ in the otoliths of Leiostomus xanthurus, although they did not test for salinity effects in their experiment. Elsdon \& Gillanders (2002) reported significant interactions between temperature and salinity on $\mathrm{Ba} / \mathrm{Ca}$ ratios in the otoliths of Acanthopagrus butcheri. Unfortunately Elsdon \& Gillanders (2002) did not report $D_{\text {Bai }}$ therefore it was difficult to draw any definitive conclusions from their study. Experiments on inorganic aragonite found that $D_{\mathrm{Ba}}$ is negatively correlated with temperature between 10 and $50^{\circ} \mathrm{C}$, with the temperature effect being an order of magnitude larger than that of $D_{\mathrm{Sr}}$ (Dietzel et al. 2003). A recent study found that temperature was also negatively correlated with $D_{\mathrm{Ba}}$ in the aragonitic protoconchs of larval gastropod mollusks (Zacherl et al. 2003). Therefore, although Ba/Ca ratios in calcified structures may have potential for recovering temperature histories, the work by Zacherl et al. (2003) remains the only convincing example of temperature effects on $\mathrm{Ba} / \mathrm{Ca}$ ratios in biogenic aragonite.

We were able to detect significant effects of salinity on $D_{\mathrm{Ba}}$, with higher values at $15 \%$ than at $25 \%$. Similar to Sr (Martin et al. 2004), absolute Ba levels in the tank waters appeared to influence otolith $\mathrm{Ba} / \mathrm{Ca}$ ratios beyond that predicted by $[\mathrm{Ba} / \mathrm{Ca}]_{\text {water }}$. We argued, based on the findings of Chowdhury \& Blust (2001, 2002), that positive, non-linear inhibition of $\mathrm{Ca}$ ions by $\mathrm{Sr}$ ions at uptake sites on branchial or intestinal membranes would result in the pattern of $[\mathrm{Sr}]_{\text {water }}$ and $[\mathrm{Sr} / \mathrm{Ca}]_{\text {otolith }}$ that we observed. Although Chowdhury \& Blust $(2001,2002)$ did not examine Ba in their experiments, it is certainly possible that $\mathrm{Ba}$ ions may also inhibit $\mathrm{Ca}$ ions in a similar manner to Sr. Whatever the mechanism, $\mathrm{Ba} / \mathrm{Ca}$ levels in larval spot otoliths reflect both $[\mathrm{Ba} / \mathrm{Ca}]_{\text {water }}$ and $[\mathrm{Ba}]_{\text {water }}$ but not temperature, and therefore $[\mathrm{Ba} / \mathrm{Ca}]_{\text {otolith }}$ is likely to accurately reflect dissolved $\mathrm{Ba}$ levels in aquatic systems. 


\section{Biomineralization and fish growth rate effects}

There is little consensus on the effect of precipitation rate effects on elemental uptake in biogenic aragonite. A couple of studies have suggested that magnesium incorporation in coral skeletons is independent of skeletal extension rates (Watanabe et al. 2001, Mitsugushi et al. 2003). We found that $D_{\mathrm{Mg}}$ was negatively correlated with both otolith precipitation rate and somatic growth rate. Precipitation rate effects are presumably kinetic in nature and occur at the site of aragonite deposition in the endolymph. Metabolic effects are likely to occur during transport of ions across membranes or within the blood plasma. However, because precipitation and growth rates covaried significantly it was impossible to determine the influence of either effect in isolation. Indeed, somatic growth, otolith precipitation rates, and temperature are often highly correlated in the field, and so it will be challenging to design an experiment to examine these effects independently.

We found no evidence that $D_{\mathrm{Mn}}$ or $D_{\mathrm{Ba}}$ in otoliths were affected by either otolith precipitation or metabolic rates. The results were similar to those obtained for $D_{\mathrm{Sr}}$ in the same experiment (Martin et al. 2004). The partition coefficients of all 3 elements are significantly lower than 1 , indicating that there clearly is a degree of physiological control over $\mathrm{Mn}, \mathrm{Sr}$, and Ba ratios in fish otoliths. Nonetheless, physicochemical properties of the ambient water appear to be primarily responsible for natural variations in concentrations of these elements.

\section{CONCLUSION}

We were able to test the effects of temperature and salinity on the elemental composition of Leiostomus xanthurus otoliths without the confounding effects of genetics, ontogeny, diet, or water compositional differences. Physicochemical properties of the ambient water appear to be primarily responsible for natural variations in concentrations of $\mathrm{Mn}, \mathrm{Sr}$, and $\mathrm{Ba}$ ratios in spot otoliths, while Mg incorporation in spot otoliths is confounded by the negative correlation with otolith precipitation and somatic growth rates. Our results draw attention to the complexity of element incorporation in otoliths, and propose that both environmental and physiological factors influence elemental ratios in fish otoliths. Thus, we emphasize the importance of acknowledging and measuring these variables to validate geochemical signatures in fish otoliths.

Acknowledgements. This research was supported by grants from the National Science Foundation to S.R.T. (OCE0134998), a grant in aid to G.B.M. from the International
Women's Fishing Association, and a PEO International Women's Organization Scholar Award to G.B.M. We would like to thank Z. Chen (LITER, Old Dominion University) for assisting with the water samples, and J. Burke, G. Fisher, and P. Crumley (NOAA, National Ocean Service, CCFHR, Beaufort, NC) for their technical support. We also thank J. Hare, M. Wuenschel, J. Potts, and P. Tester and 3 anonymous reviewers for comments on earlier drafts of the manuscript.

\section{LITERATURE CITED}

Bath GE, Thorrold SR, Jones CM, Campana SE, McLaren JW, Lam JWH (2000) Strontium and barium uptake in aragonitic otoliths of marine fish. Geochim Cosmochim Acta 64: 1705-1714

Begg GA, Cappo M, Cameron DS, Boyle S, Sellin MJ (1998) Stock discrimination of school mackerel, Scomberomorous queenslandicus, and spotted mackerel, Scomberomorus munroi, in coastal waters of eastern Australia by analysis of minor and trace elements in whole otoliths. Fish Bull 96: 653-666

Bender ML, Klinkhammer GP, Spencer DW (1977) Manganese in seawater and the marine manganese balance. Deep-Sea Res 24:799-812

Bruland KW (1983) Trace elements in seawater. In: Riley JP, Chester R (eds) Chemical oceanography. Academic Press, London, p 157-220

Buchardt B, Fritz P (1978) Strontium uptake in shell aragonite from the freshwater gastropod Limnaea stagnalis. Science 199:291-292

Byrne RH, Kump LR, Cantrell KJ (1988) The influence of temperature and $\mathrm{pH}$ on trace metal speciation in seawater. Mar Chem 25:163-181

Campana SE (1999) Chemistry and composition of fish otoliths: pathways, mechanisms and applications. Mar Ecol Prog Ser 188:263-297

Campana SE, Fowler AJ, Jones CM (1994) Otolith elemental fingerprinting for stock identification of Atlantic cod (Gadus morhua) using laser ablation ICPMS. Can J Fish Aquat Sci 51:1942-1950

Chesney EJ, McKee BM, Blanchard T, Chan LH (1998) Chemistry of otoliths from juvenile menhaden Brevoortia patronus: evaluating strontium, strontium:calcium and strontium isotope ratios as environmental indicators. Mar Ecol Prog Ser 171:261-273

Chowdhury MJ, Blust R (2001) A mechanistic model for the uptake of waterborne strontium in the common carp (Cyprinus carpio L.). Environ Sci Technol 35:669-675

Chowdhury MJ, Blust R (2002) Bioavailability of waterborne strontium to the common carp, Cyprinus carpio, in complexing environments. Aquat Toxicol 58:215-227

Crick RE, Ottensman VM (1983) Sr, Mg, Ca, and Mn chemistry of skeletal components of a Pennsylvanian and recent nautiloid. Chem Geol 39:147-163

deVilliers S, Shen GT, Nelson BK (1994) The Sr/Ca-temperature relationship in coralline aragonite: influence of variability in $(\mathrm{Sr} / \mathrm{Ca})_{\text {seawater }}$ and skeletal growth parameters. Geochim Cosmochim Acta 58:197-208

deVilliers S, Nelson BK, Chivas AR (1995) Biological controls on coral $\mathrm{Sr} / \mathrm{Ca}$ and $\delta^{18} \mathrm{O}$ reconstructions of sea surface temperatures. Science 269:1247-1249

Dietzel M, Gussone N, Eisenhauer A (2003) Co-precipitation of $\mathrm{Sr}^{2+}$ and $\mathrm{Ba}^{2+}$ with aragonite by membrane diffusion of $\mathrm{CO}_{2}$ between 10 and $50^{\circ} \mathrm{C}$. Chem Geol 203:139-151

Edmonds JS, Moran MJ, Caputi N, Morita M (1989) Trace ele- 
ment analysis of fish sagittae as an aid to stock identification: pink snapper (Chrysophrys auratus) in western Australian waters. Can J Fish Aquat Sci 46:50-54

Elderfield H, Ganssen G (2000) Past temperature and $\delta^{18} \mathrm{O}$ of surface ocean waters inferred from foraminiferal $\mathrm{Mg} / \mathrm{Ca}$ ratios. Nature 405:442-445

Elsdon TS, Gillanders BM (2002) Interactive effects of temperature and salinity on otolith chemistry: challenges for determining environmental histories of fish. Can J Fish Aquat Sci 59:1796-1808

Elsdon TS, Gillanders BM (2003) Relationship between water and otolith elemental concentrations in juvenile black bream Acanthopagrus butcheri. Mar Ecol Prog Ser 260: 263-272

Gillanders BM, Kingsford MJ (1996) Elements in otoliths may elucidate the contribution of estuarine recruitment to sustaining coastal reef populations of a temperate reef fish. Mar Ecol Prog Ser 141:13-20

Hoff GR, Fuiman LA (1995) Environmentally induced variation in elemental composition of red drum (Sciaenops ocellatus) otoliths. Bull Mar Sci 56:578-591

Kalish JM (1989) Otolith microchemistry: validation of the effects of physiology, age, and environment on otolith composition. J Exp Mar Biol Ecol 132:151-178

Kinsman DJJ, Holland HD (1969) The co-precipitation of cations with $\mathrm{CaCO}_{3}-\mathrm{IV}$. The co-precipitation of $\mathrm{Sr}^{2+}$ with aragonite between 16 and $96^{\circ} \mathrm{C}$. Geochim Cosmochim Acta 33:1-17

Klinkhammer GP, McManus J (2001) Dissolved manganese in the Columbia River estuary: production in the water column. Geochim Cosmochim Acta 65:2835-2841

Kraus RT, Secor D (2004) Incorporation of strontium into otoliths of an estuarine fish. J Exp Mar Biol Ecol 302:85-106

Lea DW, Mashiotta TA, Spero HJ (1999) Controls on magnesium and strontium uptake in planktonic foraminifera determined by live culturing. Geochim Cosmochim Acta 63:2369-2379

Martin GB, Thorrold SR, Jones CM (2004) Temperature and salinity effects on strontium incorporation in otoliths of larval spot (Leiostomus xanthurus). Can J Fish Aquat Sci 61:34-42

Milton DA, Chenery SR (2001) Sources and uptake of trace metals in otoliths of juvenile barramundi (Lates calcarifer). J Exp Mar Biol Ecol 264:47-65

Mitsuguchi T, Matsumoto E, Abe O, Uchida T, Isdale PJ (1996) $\mathrm{Mg} / \mathrm{Ca}$ thermometry in coral skeletons. Science 274:961-963

Mitsuguchi T, Matsumoto E, Uchida T (2003) Mg/Ca and Sr/Ca ratios of Porites coral skeleton: evaluation of the effect of skeletal growth rate. Coral Reefs 22:381-388

Morel FMM, Hering JG (1993) Principles and applications of aquatic chemistry. John Wiley \& Sons, New York

Morse JW, Bender ML (1990) Partition coefficients in calcite - examination of factors influencing the validity of experimental results and their application to natural systems. Chem Geol 82:265-277

Rooker JR, Secor DH, Zdanowicz VS, Itoh T (2001) Discrimination of northern bluefin tuna from nursery areas in the Pacific Ocean using otolith chemistry. Mar Ecol Prog Ser 218:275-282

Rooker JR, Secor DH, Zdanowicz VS, De Metrio G, Relini LO (2003) Identification of Atlantic bluefin tuna (Thunnus

Editorial responsibility: Otto Kinne (Editor-in-Chief), Oldendorf/Luhe, Germany thynnus) stocks from putative nurseries using otolith chemistry. Fish Oceanogr 12:75-84

Rosenthal Y, Lohmann GP (2002) Accurate estimation of sea surface temperatures using dissolution-corrected calibrations for $\mathrm{Mg} / \mathrm{Ca}$ paleothermometry. Paleoceanography 17: 1044-1049

Rosenthal Y, Field MP, Sherrell RM (1999) Precise determination of element/calcium ratios in calcareous samples using sector field inductively coupled plasma mass spectrometry. Anal Chem 71:3248-3253

Shen CC, Lee T, Chen CY, Wang CH, Dai CF, Li LA (1996) The calibration of $D[\mathrm{Sr} / \mathrm{Ca}]$ versus sea surface temperature relationship for Porites corals. Geochim Cosmochim Acta 60:2849-3858

Stecher HA III, Krantz DE, Lord CJ III, Luther GW III, Bock KW (1996) Profiles of strontium and barium in Mercenaria mercenaria and Spisula solidissima shells. Geochim Cosmochim Acta 60:3445-3456

Sunda WG, Huntsman SA (1987) Microbial oxidation of manganese in a North Carolina estuary. Limnol Oceanogr 32: $552-564$

Thorrold SR, Jones CM, Swart PK, Targett TE (1998a) Accurate classification of juvenile weakfish Cynoscion regalis to estuarine nursery areas based on chemical signatures in otoliths. Mar Ecol Prog Ser 173:253-265

Thorrold SR, Campana SE, Jones CM, McLaren JW, Lam JWH (1998b) Trace element signatures in otoliths accurately record natal river of juvenile American shad (Alosa sapidissima). Limnol Oceanogr 43:1826-1835

Thorrold SR, Latkoczy C, Swart PK, Jones CM (2001) Natal homing in a marine fish. Science 291:297-299

Turner DR, Whitfield M, Dickson AG (1981) The equilibrium speciation of dissolved components in freshwater and seawater at $25^{\circ} \mathrm{C}$ and $1 \mathrm{~atm}$ pressure. Geochim Cosmochim Acta 45:855-881

Vander Putten E, Dehairs F, Keppens E, Baeyns W (2000) High resolution distribution of trace elements in the calcite shell layer of modern Mytilus edulis: environmental and biological controls. Geochim Cosmochim Acta 64: 997-1011

von Langen PJ, Johnson KS, Coale KH, Elrod VA (1997) Oxidation kinetics of manganese (II) in seawater at nanomolar concentrations. Geochim Cosmochim Acta 61: 4945-4954

Watanabe T, Winter A, Oba T (2001) Seasonal changes in sea surface temperature and salinity during Little Ice Age in the Caribbean Sea deduced from $\mathrm{Mg} / \mathrm{Ca}$ and ${ }^{18} \mathrm{O} /{ }^{16} \mathrm{O}$ ratios in corals. Mar Geol 173:21-35

Weber JN (1973) Incorporation of strontium into reef coral skeletal carbonate. Geochim Cosmochim Acta 37: 2173-2190

Yoshinaga J, Nakama A, Morita M, Edmonds JS (2000) Fish otolith reference material for quality assurance of chemical analyses. Mar Chem 69:91-97

Zacherl DC, Manriquez PH, Paradis G, Day RW, Castilla JC, Warner RR, Lea DW, Gaines SD (2003) Trace elemental fingerprinting of gastropod statoliths to study larval dispersal trajectories. Mar Ecol Prog Ser 248:297-303

Zhong S, Mucci A (1989) Calcite and aragonite precipitation from seawater solutions of various salinities: precipitation rates and over-growth composition. Chem Geol 78: 283-299

Submitted: July 5, 2004; Accepted: November 25, 2004

Proofs received from author(s): May 16, 2005 